\title{
Spatio-Temporal Change Detection and Its Impact on the Waterbodies by Monitoring LU/LC Dynamics - A Case Study from Holy City of Ratanpur, Chhattisgarh, India
}

\author{
J. P. Koshale*† and Anupama Mahato** \\ *Chhattisgarh Space Application Center, CCOST, Raipur, C.G, India \\ **Department of Forestry, Wildlife \& Environmental Sciences, Guru Ghasidas Vishwavidyalaya, Bilaspur, C.G, India \\ $\dagger$ Corresponding author: J. P. Koshale; jaigis14@gmail.com
}

Nat. Env. \& Poll. Tech.

Website: www.neptjournal.com

Received: 17-03-2020

Revised: $20-04-2020$

Accepted: 27-05-2020

Key Words:

Wetland

Spatio-temporal change

GIS

Remote sensing

Land use land cover

\begin{abstract}
The holy city of Ratanpur is situated in the Bilaspur district of the Central Indian state of Chhattisgarh. In the past few decades, the wetlands and water bodies of Ratanpur have been subjected to various anthropogenic pressures and undergone changes in land use land cover (LULC) patterns. The paper focuses on assessing the changes in land use and land cover in and around Ratanpur city from 1989 to 2015 using LANDSAT satellite imageries. The processing of satellite imageries and quantitative assessment of LULC data was done using ArcGIS and ERDAS Imagine software. From the current study, it is evident that the numbers and quality of ponds have decreased resulting in decreased numbers and frequency of avian fauna in the area. Earlier water bodies covered an area of $3.76 \%$ which has decreased to $2.06 \%$. The reduction in areas covered under water bodies has increased in the dry watercourse area (3\%) and river bed area (0.80\%). As seen from 2015 data the built-up land areas have expanded by $2.22 \%$ as compared to 1989 . A considerable decrease in open forest area $(8.21 \%)$ and agricultural land $(3.97 \%)$ has been witnessed, whereas the area occupied by scrubland $(6.42 \%)$, wasteland $(1.18 \%)$, and built-up land $(1.99 \%)$ has increased. The Spatio-temporal LULC changes of the study area can be used to monitor, plan, and implement proper town and country planning to maintain the sustainable environment of Ratanpur city. The adverse impact of urban growth in the surface water bodies/ponds must be regulated by taking suitable conservation measures at the individual and community level for maintaining the biodiversity and aesthetic beauty of the area.
\end{abstract}

\section{INTRODUCTION}

Freshwater is a finite resource as it accounts for less than $1 \%$ of the earth's available water. As the availability of freshwater is uneven on the earth's surface, arid and semi-arid regions receive only $2 \%$ of all surface runoff yet account for $40 \%$ of the global land area. Thus, there is huge anthropogenic pressure on surface water bodies to satisfy their ever-increasing demand. Waterbodies play a very important role to fulfil human water needs. Apart from this, water bodies help in regulating the local climatic conditions, provides shelter to aquatic and avian biodiversity, recharges the groundwater aquifers, and also enhances the aesthetic beauty of the area. Globally, the surface water bodies are shrinking due to multiple factors such as an increase in population, industrialization, increased agricultural activities, etc.

The land use land cover (LULC) change is a continuous process (Mondal et al., 2016). Rapid replacement of Landcover is observed by various land-use patterns (Lambin
\& Geist 2001). The pace of change in LC to LU depends upon the growth rate of the population of the area and their needs along with the natural and economic drivers (Hund et al., 2013, Prasad et al., 2012). The choice of economic growth over ecological sustainability leads to rapid and drastic changes in LULC patterns thereby resulting in depletion of natural resources like forest, water bodies, soil, etc.(Beckerman 1992). In and around the forest area, indigenous flora and fauna are threatened by the budding of residential and built-up areas. With time the major land cover comprising of forest and water gets transformed into urban areas, settlements, built-up areas, and agricultural lands. Over a period, agricultural lands also get metamorphose into built-up areas, thereby resulting in depletion in hydrological resources and greenery (Salghuna et al.2018). The Supervised classification method has been used by various researchers (Butt et al. 2015, Rawat \& Kumar 2015, Boori et al. 2015, Islam et al. 2018, Kar et al. 2018, Nagarajan \& Poongothai 2011, Rouse et al. 1973, Alcamo et al., 2010) to study the LULC change of the global landscapes. 
Alteration in wetland due to LULC change has been observed by various researchers (Ozsahin et al., 2018, Praveen et al., 2018 and Alam et al., 2011). The anthropogenic activities and development processes affect the habitat structure thereby affecting the natural properties such as water, wetlands, and biodiversity (Gibbard et al., 2005, Dhere \& Pondhe 2018). analyses the impact of unregulated and unplanned development on the Bhima river of the Pune district. Spatial changes in the LULC pattern of the Manas River Basin have been studied and analyzed between the periods of 1976-2006 (Zhang et al., 2012). Two decadal changes in the LULC pattern of Delhi NCR (National Capital Region) has been studied by (Suzanchi \& Kaur 2011) by using RS \& GIS technology.

The holy city of Ratanpur situated in the Central Indian state of Chhattisgarh has a long historical record. The city was established by Ratnaraja (Grandson of Kalingaraja). In 1407, the Ratanpur kingdom was divided into two parts- one is Ratanpur and the other was Raipur (Jha 1997). The ancient capital of Chhattisgarh is famous for its historical importance and culture. The administrative unit of Ratanpur lies under Nagar panchayat of Bilaspur district of Chhattisgarh. Ratanpur is famous for its religious monuments such as Mahamaya Temple, Baba Bhairavnath Temple, Bhuddeshwar Shiva Temple, Ratneshwar Mahadev Temple, Girijaban Hanuman Temple, Lakhani Devi Temple, Ram Tekri, Ashok Vatika, and Jagannath Temple, etc. Apart from that, the area is bestowed by good scenic beauty such as undulating landscapes, rich forests, agricultural fields, and a large number of ponds which attracts the attention of a large number of tourists. Various studies have also been done on the wetlands and aquatic fauna and floral diversity of the Ratanpur area (Dwivedi 2014, Singh \& Shahi 2017, Porte et al. 2018, Dwivedi \& Singh 2017) but no studies have been conducted on LULC changes.

\section{STUDY AREA}

The Ratanpur city is located in Bilaspur district of Chhattisgarh, India. It is also known as a city of ponds due to the presence of numerous surface water bodies and is situated in Kota block at a distance of about 25 kilometres from Bilaspur city (Fig. 1). The geographical extent of the place lies between $82^{\circ} 16^{\prime} 66.18^{\prime \prime} \mathrm{E}-82^{\circ} 13^{\prime} 14.28^{\prime \prime} \mathrm{E}$ and $22^{\circ} 30^{\prime} 51.20^{\prime \prime} \mathrm{N}-22^{\circ} 26^{\prime} 71.58^{\prime \prime} \mathrm{N}$ latitude, having an altitude of $306 \mathrm{~m}$ above mean sea level. The area is characterized by three distinct seasons such as summer, monsoon, and winter. The average annual rainfall of the Bilaspur district between the periods of 1990-2015 was $1211.89 \mathrm{~mm}$ (Fig. 2).

\section{Population Status of Ratanpur}

Ratanpur area comes under Nagar Palika of Bilaspur district of Chhattisgarh state, covering the 15 wards. According to the Census 2011, it consists of a total of 10,806 households, with a population of 49,272 (25268 males and 24004 females). During the year 2001, 39678 individuals resided in the area. In the year 2001 the population density of the area from 468.01 people $/ \mathrm{km}^{2}$ while in the year 2011 it reached 581.17 people $/ \mathrm{km}^{2}$. A demographic detail of the study area was collected from Census data for the years 2001 and 2011 by the Government of India.

\section{MATERIALS AND METHODS}

\section{Data Used}

The satellite imageries were provided by NASA-GLCF (Global Land Cover Facility) and USGS (United States Geological Survey), the satellite imageries were downloaded from the USGS website (www.usgs.com). The Landsat satellite imageries for 1989, 1995, 2000, 2005, 2010, and 2015 have been used for image processing and interpretation. Cloud free satellite imageries during the winter months were selected to minimize the seasonal variation in data due to spectral reflectance. The Survey of India (SOI) Toposheet number

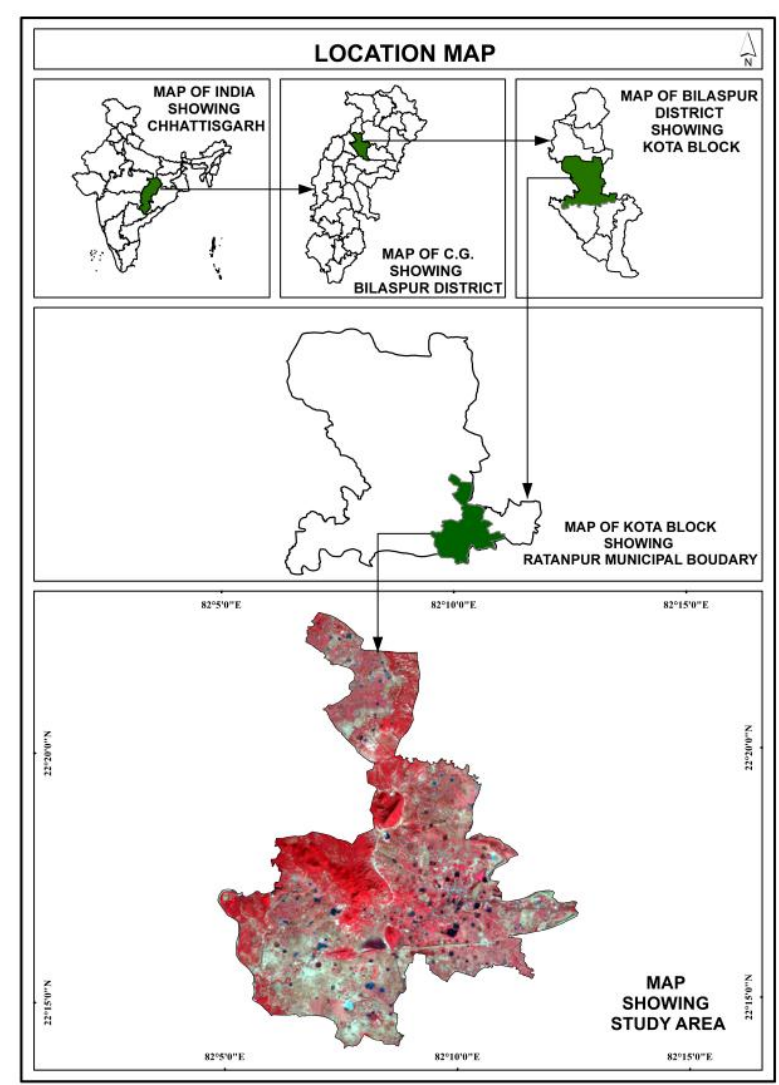

Fig. 1: Location map of Ratanpur. 
64J03, 64J04 at 1:50,000 scales were used for the study. The master plan of Ratanpur municipal area is downloaded from Town and Country Planning, Government of Chhattisgarh website (www.town\&countryplanning.com). Characteristics of Landsat satellite data are illustrated in Table 1.

\section{Image Processing}

The LULC change detection and analysis is done using Landsat satellite data. The LULC map for the years 1989, 1995, 2000, 2005, 2010 and 2015 was prepared using ArcGIS, and supervised classification has been done using ERDAS Imagine software. Geo-referencing of master plan map was performed using 4-6 Ground Control Points (GCP) collected from Landsat satellite data of 2015 and digitalization of study area boundary using Georeferenced Ratanpur Nagar Palika map. Pre-processing of satellite imageries includes processes such as layer stacking False Colour Composition (FCC) format of band combination 3, 4, and 5 bands followed by masking of the study area by using the subset tool. The subset imageries are then projected to UTM (Universal Transverse Mercator) zone $43 \mathrm{~N}$. As six different satellite imageries were used during the study, supervised classification of the satellite data was performed using Maximum Likelihood Method taking into consideration the LULC classes of the area. Supervised classification was done in ERDAS Imagine software and map composition has been prepared using ArcGIS software. The thematic maps derived were assessed for change in LULC classes from 1989 to 2015. The later LULC maps (2010 and 2015) were considered for changes mostly focusing on built-up land. Validation of past LULC changes with 2015 data was useful in knowing the extent of increase in built-up class, dry watercourse and reduction in water bodies, etc.

\section{Change Detection}

For each LULC categories, the magnitude of change was

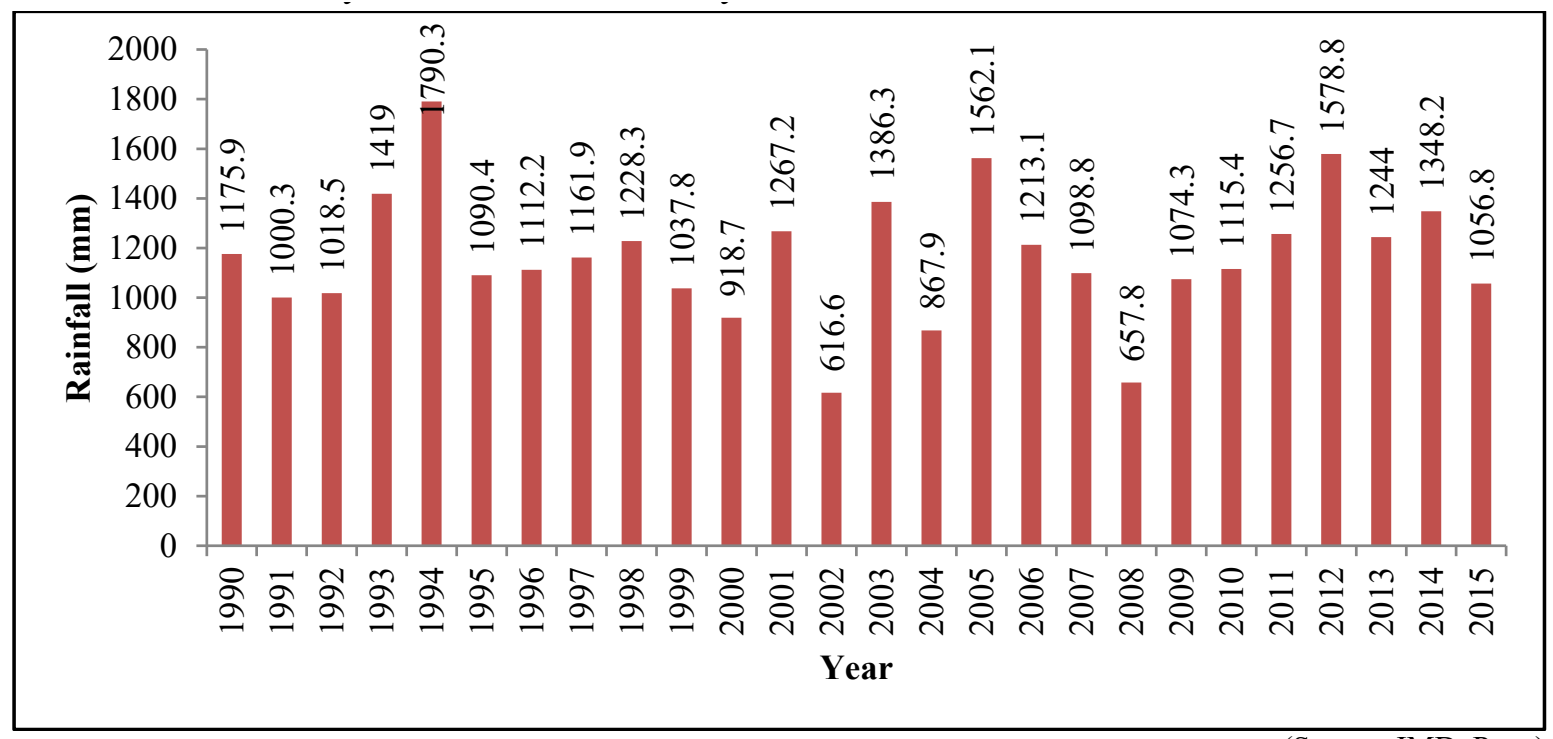

(Source: IMD, Pune)

Fig. 2: Average annual rainfall (mm) of Bilaspur district.

Table. 1: Description of the satellite imageries.

\begin{tabular}{|lllll|}
\hline Satellite & Sensor & Path/ Row & Acquisition Date & Spatial Resolution (m) \\
\hline Landsat 4 & TM & $142 / 45$ & $09 / 12 / 1989$ & 30 \\
Landsat 4 & TM & & $10 / 12 / 1995$ & 30 \\
Landsat 7 & ETM+ & & $15 / 12 / 2000$ & 30 \\
Landsat 4 & TM & & $19 / 11 / 2005$ & 30 \\
Landsat4 & TM & $19 / 12 / 2010$ & 30 & 30 \\
Landsat 8 & OLI/TIRS & & $01 / 12 / 2015$ & 30 \\
\hline
\end{tabular}

Note: TM - (Thematic Mapper), ETM+ - (Enhanced Thematic Mapper Plus), OLI/TIRS - (Operational Land Imager/Thermal Infra-Red Sensor) 
calculated by subtracting the area covered by the second year and the initial year as shown in the equation (1)

Magnitude of change $=$ magnitude of new year - magnitude of previous year

Change in percentage for each LULC categories was calculated by dividing the magnitude of change by the initial year and multiplied by 100 as shown in the equation (2)

$$
\text { Change }(\%)=\frac{\text { magnitude of change } \times 100}{\text { Initial year }}
$$

The annual rate of change for each LULC categories was calculated by subtracting the final year to initial year, which was further divided by the number of study year, i.e. 19891995 (6 years), 1995-2000 (5 years), 2000-2005 (5 years), 2005 -2010 (5 years), 2010-2015 (5 years) respectively using the equation (3)

Annual rate of change $=\frac{\text { Final year-initial year }}{\text { Number of years }}$

\section{Accuracy Assessment}

A classification is incomplete until its accuracy has been assessed. The term accuracy means the level of agreement between labels assigned by the classified and class allocation based on ground data collected by the user, known as test data (Pal \& Mather 2006). The accuracy assessment of supervised classification imageries was performed in ERDAS IMAGINE software using Google earth by synchronizing the Ground Location Points. About 100 ground locations were randomly selected in the classified imageries and with the help of the Google earth synchronization tool accuracy assessment of the supervised imageries was performed. It includes an assessment of overall accuracy, kappa statistics, producer's accuracy, and user's accuracy of the LULC classes for the supervised imageries of the year 1989, 1995, 2000, 2005, 2010 , and 2015 , respectively.

\section{RESULTS AND DISCUSSION}

The LULC classes are categorized into nine groups including (1) Agriculture land (2) Dense forest (3) Open forest (4) Scrubland (5) Wasteland (6) Built-up land (7) Waterbody (8) Dry watercourse and (9) Riverbeds. Water bodies include all the surface water bodies of the area filled with water. The dry watercourse is the area which was earlier covered by water bodies and is dried at present and the area of the riverbed is the areas adjoining the water body which are covered by sand. The aerial distribution of various LULC classes for the years 1989, 1995, 2000, 2005, 2010, and 2015 was prepared and their change scenario in between different time frames are shown in Table 2 and Table 3. After the classification of satellite imageries based on the above LULC categories, relevant map layouts were prepared on 1:70,000 scales (Fig. 3)

\section{Dynamics of LULC Change of Ratanpur during the Year 1989 and 1995}

Landsat TM imageries have been used to assess the past LULC pattern of the study area. The 9 LULC categories have been identified for the years 1989 and 1995 as shown in Table 2 and fig. 3. A total of $84.78 \mathrm{~km}^{2}$ was estimated for the whole Ratanpur area. Among the above land use categories, agricultural land remained the dominant land use type (covering $52.10 \mathrm{~km}^{2}$ and $52.16 \mathrm{~km}^{2}$ ) followed by open forest during the years 1989 and 1995 . The areas covered under open forest decreased from $16.82 \mathrm{~km}^{2}(19.84 \%)$ in the year 1989 to 10.40 $\mathrm{km}^{2}(12.27 \%)$ in 1995 . During six years, the areas covered under scrubland, wasteland, and built-up land increased by $4.53 \%, 1.55 \%$, and $0.65 \%$, whereas a decline in trend has been observed for the dense forest and open forest area by $0.32 \%$ and $7.57 \%$ respectively. The surface water bodies covered an area of $3.19 \mathrm{~km}^{2}(3.76 \%)$ during the year 1989 which reduced to $2.16 \mathrm{~km}^{2}(2.55 \%)$ by the year 1995 . This reduction in the water body area positively coincides with an increase of dry watercourse area $(1.97 \%)$ and riverbed occupied area $(0.34$ $\%$ ) between the periods of $1989-1995$.

\section{Dynamics of LULC Change of Ratanpur During the Year 1995 and 2000}

Between the years 1995 and 2000, the agricultural area increased by $2.17 \mathrm{~km}^{2}(2.56 \%)$. Further reduction in areas covered under open forest area $(1.74 \%)$, wasteland (1.15 $\%)$, riverbed $(0.37 \%)$. The LULC categories which showed an increasing trend during the period was dense forest (1.45 $\%)$ and scrubland $(0.16 \%)$. The water body area increased by $0.53 \mathrm{~km}^{2}(0.62 \%)$, which resulted in a reduction in dry watercourse area by $1.52 \mathrm{~km}^{2}(1.79 \%)$, this rise in water body area is due to good rainfall over the study area and its catchments during this period.

\section{Dynamics of LULC Change of Ratanpur During the Year 2000 and 2005}

A total of nine LULC classes were identified similar to the previous years. It was noticed that the agricultural land was still the dominant land use type which shared $54.33 \mathrm{~km}^{2}$ and $48.91 \mathrm{~km}^{2}$ during 2000 and 2005. The areas covered under open forest and scrubland have increased by $5.72 \%$ and $0.55 \%$, whereas dense forest area reported decreasing by $2.01 \%$. The dry watercourse area increased by $1.78 \%$, followed by the riverbed area by $0.24 \%$.

\section{Dynamics of LULC Change of Ratanpur During the Year 2005 and 2010}

During the years 2005 and 2010, agricultural land increased from $48.91 \mathrm{~km}^{2}$ to $50.29 \mathrm{~km}^{2}$. The other LULC categories 
such as built-up land $(0.37 \%)$, dense forest $(0.72 \%)$, dry watercourse $(0.90 \%)$, river bed $(0.46 \%)$, scrubland $(0.44 \%)$, scrubland $(0.33 \%)$ have shown increasing trend between the interval of 5 years. The decreasing trend has been reported in areas covered under open forest $(3.63 \%)$ and water bodies $(1.22 \%)$.

\section{Dynamics of LULC Change of Ratanpur During the Year 2010 and 2015}

During this period, the open forest area continues to decrease from $10.7 \mathrm{~km}^{2}(12.62 \%)$ to $9.86 \mathrm{~km}^{2}$ (11.63\%), reduction in water body area have also been reported by $1.44 \mathrm{~km}^{2}(1.69 \%)$ followed by dense forest by $0.13 \mathrm{~km}^{2}$ $(0.15 \%)$. The conversion of dense forest area, open forest area, and agricultural land into scrubland $(6.42 \%)$ has also been reported during this time frame. The LULC categories which recorded an increasing trend are dry watercourse area $(3 \%)$, built-up land (1.99\%), riverbed area (1.43\%), and wasteland (1.19\%).

The LULC pattern of the study area was depicted in Fig. 3. Here the yellow patch indicates agricultural land which was more prominent in the Ratanpur area as agricultural activities are the main source of income for the residents. The dark green patch indicates the dense forest area in the western and south western region of the study area, whereas the light green colour indicates the open forest area. Red colour shows the built-up land, pink indicates a dry watercourse, brown colour indicates the wasteland area. A blue shade represents water bodies (dark blue) and riverbed (light blue).

Table 2: Category wise LULC distribution of Ratanpur (1989-2015).

\begin{tabular}{|c|c|c|c|c|c|c|c|c|c|c|c|c|}
\hline \multirow[t]{2}{*}{ LULC category } & \multicolumn{2}{|l|}{1989} & \multicolumn{2}{|l|}{1995} & \multicolumn{2}{|l|}{2000} & \multicolumn{2}{|l|}{2005} & \multicolumn{2}{|l|}{2010} & \multicolumn{2}{|l|}{2015} \\
\hline & $\begin{array}{l}\text { Area } \\
\text { (sq. } \\
\text { km) }\end{array}$ & $\begin{array}{l}\text { Area } \\
(\%)\end{array}$ & $\begin{array}{l}\text { Area } \\
(\mathrm{sq} . \mathrm{km})\end{array}$ & $\begin{array}{l}\text { Area } \\
(\%)\end{array}$ & $\begin{array}{l}\text { Area } \\
\text { (sq. } \\
\mathrm{km})\end{array}$ & $\begin{array}{l}\text { Area } \\
(\%)\end{array}$ & $\begin{array}{l}\text { Area } \\
\text { (sq. km) }\end{array}$ & $\begin{array}{l}\text { Area } \\
(\%)\end{array}$ & $\begin{array}{l}\text { Area } \\
\text { (sq. } \\
\text { km) }\end{array}$ & $\begin{array}{l}\text { Area } \\
(\%)\end{array}$ & $\begin{array}{l}\text { Area } \\
(\mathrm{sq} . \\
\mathrm{km})\end{array}$ & $\begin{array}{l}\text { Area } \\
(\%)\end{array}$ \\
\hline Agriculture Land & 52.10 & 61.45 & 52.16 & 61.52 & 54.33 & 64.08 & 48.91 & 57.69 & 50.29 & 59.32 & 48.74 & 57.49 \\
\hline Built Up Land & 1.88 & 2.22 & 2.43 & 2.87 & 2.65 & 3.13 & 2.66 & 3.14 & 2.98 & 3.51 & 3.57 & 4.21 \\
\hline Dense Forest & 4.07 & 4.80 & 3.8 & 4.48 & 5.03 & 5.93 & 3.32 & 3.92 & 3.93 & 4.64 & 3.94 & 4.65 \\
\hline Dry Water Course & 0.90 & 1.06 & 2.57 & 3.03 & 1.05 & 1.24 & 2.56 & 3.02 & 3.32 & 3.92 & 3.44 & 4.06 \\
\hline Open Forest & 16.82 & 19.84 & 10.4 & 12.27 & 8.93 & 10.53 & 13.78 & 16.25 & 10.7 & 12.62 & 9.86 & 11.63 \\
\hline River Beds & 0.68 & 0.80 & 0.97 & 1.14 & 0.65 & 0.77 & 0.86 & 1.01 & 1.25 & 1.47 & 1.89 & 2.23 \\
\hline Scrub Land & 3.19 & 3.76 & 7.03 & 8.29 & 7.16 & 8.45 & 7.63 & 9.00 & 8 & 9.44 & 8.63 & 10.18 \\
\hline Waste Land & 1.95 & 2.30 & 3.26 & 3.85 & 2.29 & 2.70 & 2.12 & 2.50 & 2.4 & 2.83 & 2.96 & 3.49 \\
\hline Water Body & 3.19 & 3.76 & 2.16 & 2.55 & 2.69 & 3.17 & 2.94 & 3.47 & 1.91 & 2.25 & 1.75 & 2.07 \\
\hline Total & 84.78 & 100.00 & 84.78 & 100.00 & 84.78 & 100.00 & 84.78 & 100.00 & 84.78 & 100.00 & 84.78 & 100.00 \\
\hline
\end{tabular}

Source: Landsat satellite imageries from 1989-2015 and data extraction as well as compilation done by authors using ArcGIS and ERDAS IMAGINE software.

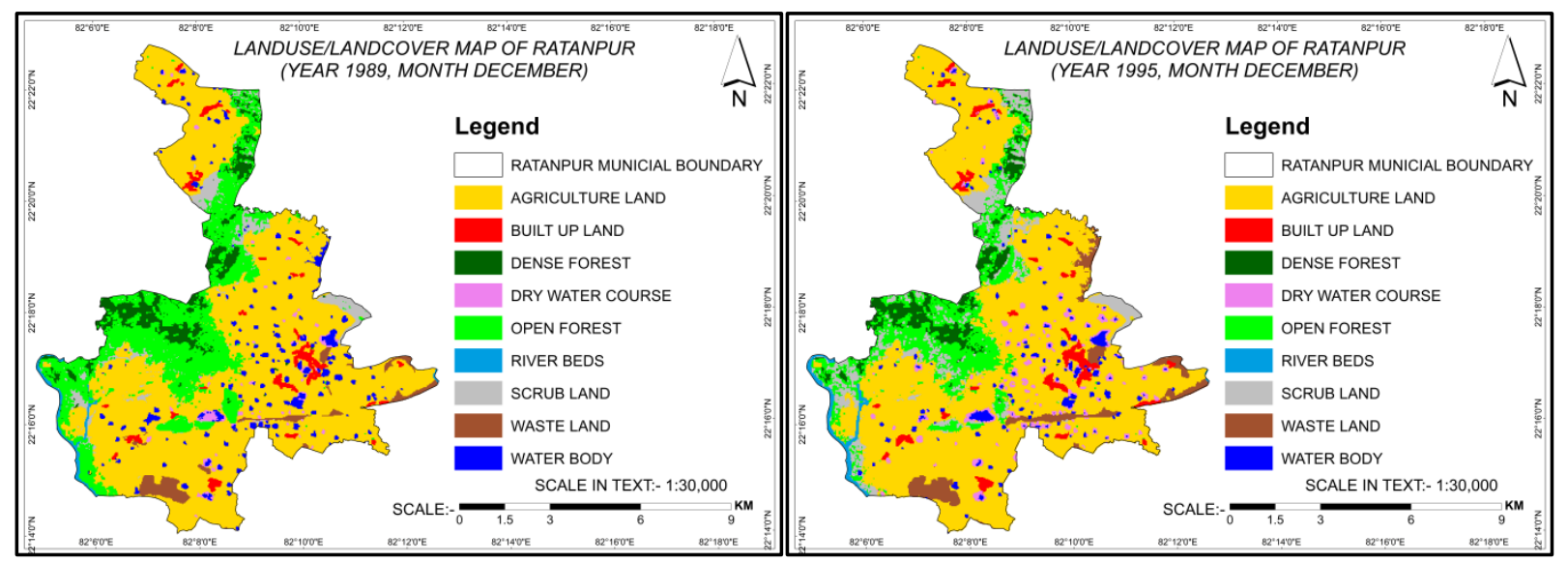

Fig. Cont.... 

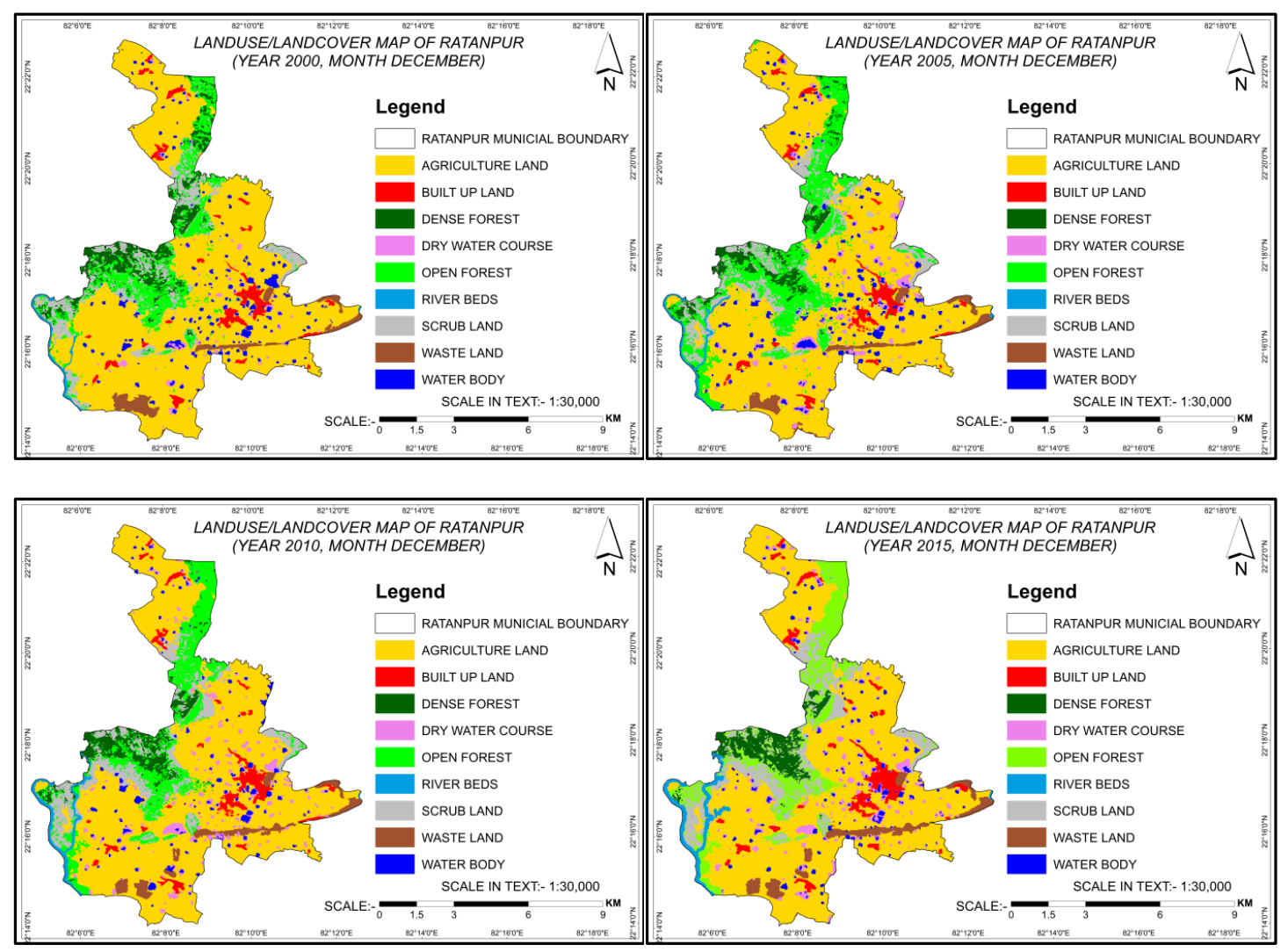

Fig. 3: Spatiotemporal LULC map of Ratanpur for the years 1989, 1995, 2000, 2005, 2010, and 2015.

\section{Accuracy Assessment of the Supervised Classification Imageries}

The accuracy assessment of the supervised imageries was performed taking into consideration the LULC classes. The producers' and users' accuracy of the LULC classes were illustrated in Table 4. The overall accuracy of $92 \%, 97 \%$, $95 \%, 96 \%, 93 \%$ and $87 \%$ were recorded for the year 1989 , 1995, 2000, 2005, 2010 and 2015. The Kappa coefficient which lies on a scale between 0 (no reduction in error) and 1 (complete reduction of error) was also analyzed for the above-mentioned imageries. The Kappa statistics value of $0.8619,0.9447,0.8963,0.9406,0.8942$ and 0.7981 was recorded for the year 1989, 1995, 2000, 2005, 2010 and 2015.

\section{Relative Changes in LULC Dynamics of the Study Area from 1989-2015}

Overall change dynamics in the LULC pattern of the Ratanpur area show a major reduction in open forest area $(8.21 \%)$ followed by agricultural land $(3.97 \%)$. The decline in agricultural activities can be positively correlated with a decrease in water bodies (1.70\%), as most of the agricultural land of the area is rain-fed. Reduction in surface water bodies resulted in a rise in the dry watercourse area (3\%) which was earlier covered with water. The extent of change in areas covered by water bodies changes from year to year due to variation in temperature and rainfall of the region. Due to the dumping of wastes and effluents, the water bodies are converting into a eutrophic state resulting in the growth of aquatic weeds floating over the water as shown in Fig. 4

(Porte \& Gupta 2017) have studied the comparative distribution pattern of wetland birds of polluted and unpolluted ponds of Ratanpur. Their study revealed that scared ponds such as Mahariya, Jagannath, Gireejaban, Dulahara, Bikma, and Bairagban Ponds remain unpolluted due to regional beliefs, but the ponds without having religious importance (Kaira, Bhedimuda, Krishnarjuni and Rateshwar Ponds) are more polluted due to anthropogenic influences. Apart from irrigating the crops these water bodies provide shelter to a large number of wetland birds along with migratory avian species, thereby very important to maintain the ecological integrity of the area.

Various developmental activities, a rise in tourist visitors, and human encroachment have increased in settlements. Accelerated anthropogenic activities such as increased irrigation, dumping of garbage and sewage in the water bodies 

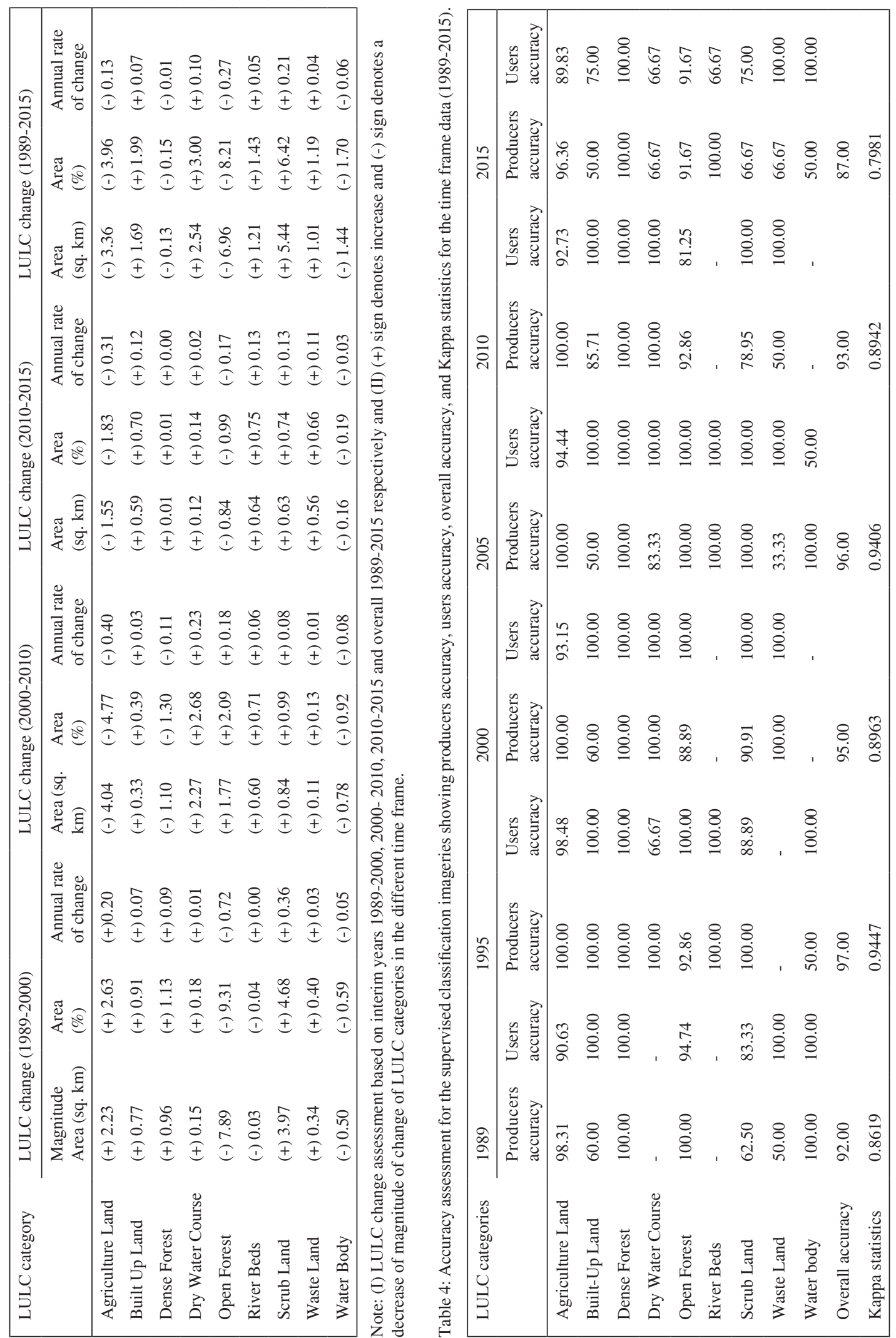


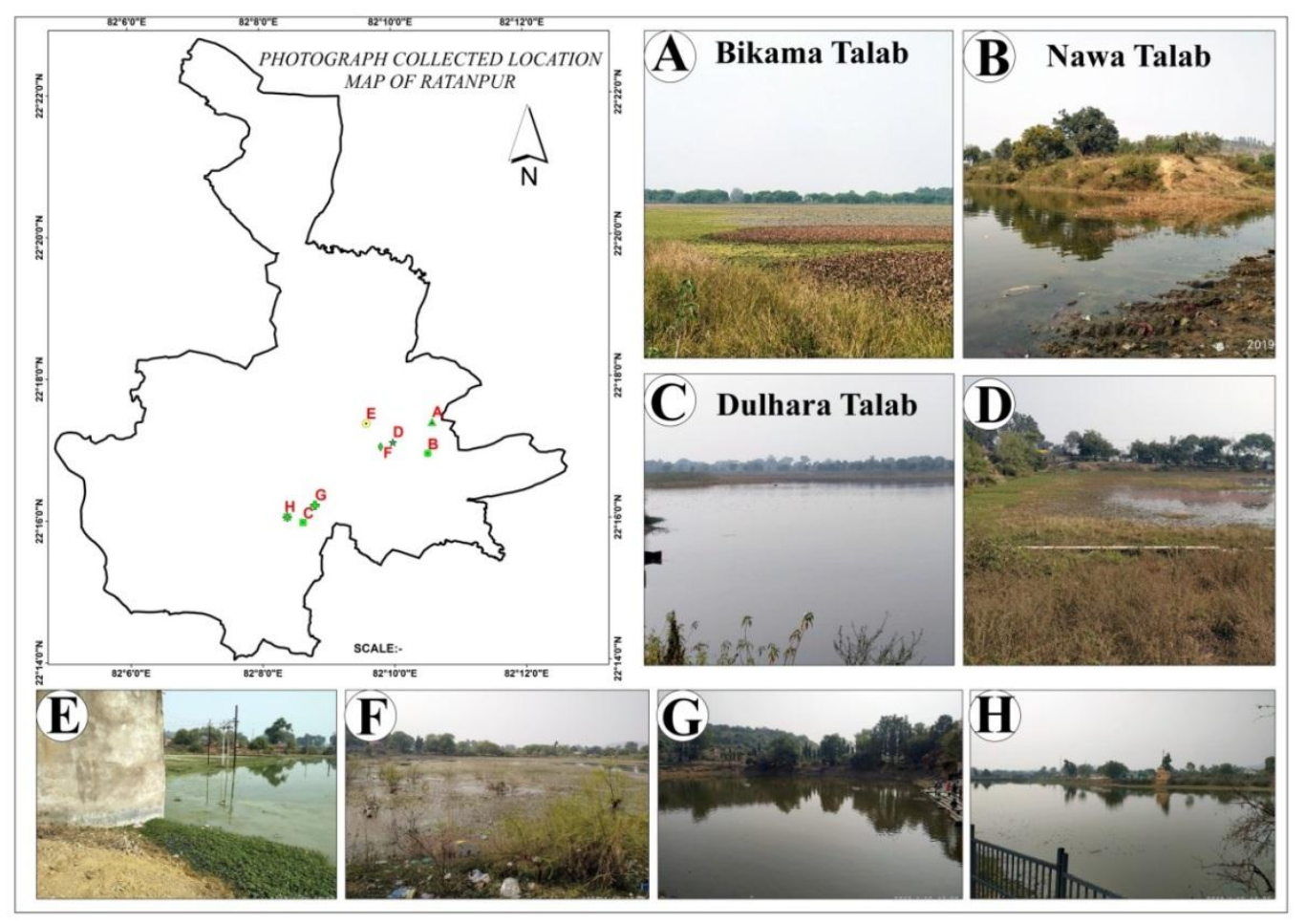

(Photo courtesy: Mr. Jai Prakash Koshale)

Fig. 4: Drivers of change in wetlands A) Growth of weed (A, D, E) ii) Dumping of waste, garbage, etc. on the ponds (B, F).

resulting in habitat fragmentation and loss thereby leading to a decline in numbers and quality of the existing ponds in the area. The growing demand for water resources is likely to have negative consequences for ecosystems and the wildlife they support (Stommel et al. 2016). Large-scale utilization of water is responsible for a significant reduction in water level and its quality (Stommel et al. 2015) during the dry seasons.

During 26 years, the built-up land has increased by $1.99 \%$ with an annual rate of change of $0.07 \mathrm{~km}^{2}$. (Suzanchi \& Kaur 2011) reported the transformation of $13.25 \%$ of water bodies into built-up land in the NCR region, India which noticed the decline in water bodies by (49.5\%) during 1998-2006. Wasteland, scrubland and river bed area has also reported an increase in the due course of time. Increased urban area and settlement during the period are depicted in Fig. 3. The influence of anthropogenic disturbance was recorded higher in the central portion of the area, affecting the ponds of that area. Information obtained by LULC change detection will help in providing better options for effective management of the land and water resources and also cope with the rise in population due to urbanization. Thus, the dynamics of
LULC changes and its consequences is essential to study and implement better planning for developmental projects along with sustained survival of biodiversity and hydrology of the area.

\section{CONCLUSION}

Geospatial technology such as RS and GIS has been used to study the LULC change dynamics of Ratanpur city between the period of 1989 and 2015. The results show a major reduction in the open forest area $(8.21 \%)$ which is directly or indirectly related to the conversion of scrubland, wasteland, and built-up land. The built-up area of the study area has been reported to increase by $1.69 \mathrm{~km}^{2}(1.99 \%)$. Huge urban expansion and developmental activities were developed around the area which is damaging the wetlands and ecology of the area. The water bodies covered an area of $3.76 \%$ during the year 1989 decreased to $2.07 \%$ by the year 2015 . This decrease in water body area increased the dry watercourse area (3\%) and river bed area (1.43\%). As, the agricultural activity is rain-fed and partially on the irrigation by the available surface water bodies, resulting in a decrease in the agricultural area by $3.97 \%$ during this 
period. The study may also be used to assess the change in water bodies and their conversion into other land use categories. Thus, the present study may provide very important data for urban expansion and utilization/overexploitation of water resources. The information may also use for the restoration and conservation of water bodies in and around the city.

The study demonstrates the potential of using Landsat satellite imageries in LULC change detection and assessment and provides huge potential for implementing proper urban planning and management. Because of capital city development, emphasis must be given to sustained economic development by taking into consideration environmental and natural resources such as water bodies, land, and forest as important factors. Also, there is an urgent need for sustainable utilization of water resources, formulation of climate adaption strategies, making the people and government aware about shrinking water resources as well as taking urgent action for conservation and harvesting of water.

\section{ACKNOWLEDGEMENTS}

The authors are thankful for USGS for providing satellite imageries of the study area. The authors also thank Ratanpur Nagar Palika for providing the Nagar Palika map. The authors are grateful to the Chhattisgarh council of science and technology (CCOST) for providing a lab facility for this research work.

\section{REFERENCES}

Alam, A., Rashid, S. M., Bhat, M. S. and Sheikh, A. H. 2011. Impact of land use/land cover dynamics on Himalayan wetland ecosystem. Journal of Experimental Sciences, 2(3): 60-64.

Alcamo, J., Flörke, M., Märker, M., Alcamo, J., Flörke, M. and Märker, M. 2010. Future long-term changes in global water resources driven by socio-economic and climatic changes. Hydrological Sciences Journal, 52(2): 247-275.. https://doi.org/10.1623/hysj.52.2.247

Butt, A., Shabbir, R., Ahmad, S. S., Aziz, N., Nawaz, M. and Shah, M. T. A. 2015. Land cover classification and change detection analysis of Rawal watershed using remote sensing data. J. Biol. Environ. Sci., 6(1): 236-248.

Beckerman, W. 1992. Economic growth and the environment: Whose growth? Whose environment? World Development, 20(4), 481-496. https://doi.org/10.1016/0305-750X(92)90038-W

Boori, M. S., Voženílek, V. and Choudhary, K. 2015. Land use/cover disturbance due to tourism in Jeseníky Mountain, Czech Republic: A remote sensing and GIS-based approach. The Egyptian Journal of Remote Sensing and Space Science, 18(1): 17-26. https://doi. org/10.1016/J.EJRS.2014.12.002

Dhere, A. M. and Pondhe, G. M. 2018. Application of geo-spatial technology for analyzing impact on Bhīma River Pune district. Eco Chronicle, 24-30.

Dwivedi, S. 2014. Culture and Tradition of Chhattisgarh. 3(10): 13-15. Dwivedi, U. and Singh, R. K. 2017. Biodiversity of migratory birds in
Khutaghat, Ratanpur District, Bilaspur (C.G.). World Journal of Pharmacy and Pharmaceutical Sciences, 6(7): 1148-1155

Gibbard, S., Caldeira, K., Bala, G., Phillips, T. J. and Wickett, M. 2005. Climate effects of global land cover change. Geophysical Research Letters, 32(23): 1-4. https://doi.org/10.1029/2005GL024550

Hund, K., Megevand. C., Gomes. E. P., Miranda, M. and Reed. E. 2013. Deforestation Trend in the Congo Basin: Mining World Bank, Washington, DC.

Islam, K., Jashimuddin, M., Nath, B. and Nath, T. K. 2018. Land use classification and change detection by using multi-temporal remotely sensed imagery: The case of Chunati wildlife sanctuary, Bangladesh. The Egyptian Journal of Remote Sensing and Space Science, 21(1): 37-47. https://doi.org/10.1016/J.EJRS.2016.12.005

Jha, M. 1997. Anthropology of Ancient Hindu Kingdoms: A Study in Civilizational Perspective. MD Publications Pvt. Ltd., pp 65.

Kar, R., Obi Reddy, G. P., Kumar, N. and Singh, S.K. 2018. Monitoring spatio-temporal dynamics of urban and peri-urban landscape using remote sensing and GIS - A case study from Central India. The Egyptian Journal of Remote Sensing and Space Science, 21(3): 401411. https://doi.org/10.1016/J.EJRS.2017.12.006

Lambin, E.F. and Geist, H. J. 2001. Global land-use and land-cover change: What have we learned so far. Global Change Newsletter, 46: 27-30.

Mondal, M. S., Sharma, N., Garg, P. K. and Kappas, M. 2016. Statistical independence test and validation of CA Markov land use land cover (LULC) prediction results. Egyptian Journal of Remote Sensing and Space Science, 19(2): 259-272. https://doi.org/10.1016/j. ejrs.2016.08.001

Nagarajan, N. and Poongothai, S. 2011. Trend in Land Use/Land Cover Change Detection by RS and GIS Application. 3(September): 263269.

Ozsahin, E., Duru, U. and Eroglu, I. 2018. Land use and land cover changes (LULCC), a key to understand soil erosion intensities in the Maritsa Basin. Water, 10(335): 1-15

Porte, D.S. and Gupta S. 2017. Assessment of distribution patterns of wetland birds between unpolluted and polluted ponds at Ratanpur; district Bilaspur, Chhattisgarh, India, Indian J. Sci. Res., 12(2): 204-215

Pal, M. and Mather, P.M. 2006. Some issues in the classification of DAIS hyperspectral data. Int. J. Remote Sens., 27(14): 2895-2916.

Porte D.S., Gupta, S. and Kankariya 2018. Temporal pattern in foraging behavior of the Indian pond heron, Ardeola grayii at Ratanpur, Chhattisgarh, India. Biological Rhythm Research, 49(5): 761-771.

Prasad, P., Rama Chandra, Lakshmi, P., Mamtha, Rajan, K. S., Bhole, Vijaya and Dutt, C.B.S. 2012. Tsunami and tropical island ecosystem - A mega-analysis of the studies in Andaman and Nicobar Islands. Biodiversity Conservation, 21(2): 309-322.

Praveen, S., Basheer, J. and Praveen, B. 2018. A literature review on land use land cover changes. Int. J. Adv. Res., 6(7): 1-6.

Rouse, J. W., Haas, R. H., Schell, J. A. and Deering, D.W. 1973. Monitoring vegetation systems in the Great Plains with ERTS. Third ERTS Symposium, NASA SP-351, Washington DC, 10-14 December 1973, 309-317.

Rawat, J. S. and Kumar, M. 2015. Monitoring land use/cover change using remote sensing and GIS techniques: A case study of Hawalbagh block, district Almora, Uttarakhand, India. The Egyptian Journal of Remote Sensing and Space Science, 18(1): 77-84. https://doi.org/10.1016/J. EJRS.2015.02.002

Salghuna, N. N., Rama Chandra Prasad, P. and Asha Kumari, J. 2018. Assessing the impact of land use and land cover changes on the remnant patches of Kondapalli reserve forest of the Eastern Ghats, Andhra Pradesh, India. The Egyptian Journal of Remote Sensing and Space Science, 21(3): 419-429. https://doi.org/10.1016/J. EJRS.2018.01.005 
Singh, R.S. and Shahi S. 2017. Diversity of medicinal plants of Ratanpur region of Bilaspur district (Chhattisgarh), Journal of Medicinal Plants Studies, 5(2): 276-281.

Stommel, C., Hofer, H. and East, M.L. 2015. The effect of reduced water availability in the Great Ruaha River on the vulnerable Common Hippopotamus in the Ruaha National Park, Tanzania. PLOS ONE,11(6): 1-18.

Stommel, C., Hofer, H., Grobbel, M. and East, M.L. 2016. Large mammals in Ruaha National Park, Tanzania, dig for water when water stops flowing and water bacterial load increases. Mamm Biol., 81: 21-30. Suzanchi, K. and Kaur, R. 2011. Land use land cover change in National Capital Region of India: A remote sensing \& GIS based two decadal spatial-temporal analyses. Procedia - Social and Behavioral Sciences, 21: 212-221. https://doi.org/10.1016/j. sbspro.2011.07.044

Zhang, Q., Xu, H., Fu, J., Yu, P. and Zhang, P. 2012. Spatial analysis of land use and land cover changes in recent 300 years in Manas River Basin. Procedia Environmental Sciences, 12: 906-916. 